Байкадамова Айнур Маратовна, $\mathrm{PhD}$ НАО «КазНИТУ имени К.И.Сатпаева» г. Алматы, Казахстан e-mail: ainurchuk90@mail.ru ORCID ID 0000-0001-7081-7372

\title{
ГЕОЛОГИЧЕСКОЕ СТРОЕНИЕ И ГИДРОГЕОЛОГИЧЕСКИЕ УСЛОВИЯ ЖАРКЕНТСКОГО АРТЕЗИАНСКОГО БАССЕЙНА
}

Baikadamova Ainur Maratovna, $\mathrm{PhD}$ Satbayev University, Almaty, Kazakhstan e-mail: ainurchuk90@mail.ru ORCID ID 0000-0001-7081-7372

\section{GEOLOGICAL STRUCTURE AND HYDROGEOLOGICAL CONDITIONS OF THE ZHARKENT ARTESIAN BASIN}

\begin{abstract}
Annotation: This article deals with the hydrogeological conditions of the Zharkent artesian basin. Briefly described are stratigraphy and lithology, the tectonics of the region, the history of geological development, hydrogeological conditions.
\end{abstract}

Keywords: Artesian basin, aquifer complex, thermal water horizons, well.

Аннотация: $B$ данной статье рассматриваются гидрогеологические условия Жаркентского артезианского бассейна. Кратко описываются стратиграфия и литология, тектоника района, история геологического развития, гидрогеологический условия.

Ключевые слова: Артезианский бассейн, водоносный комплекс, термоводосные горизонты, скважина.

В административном отношении территория исследований расположена в пределах Панфиловского района Алматинской области. На востоке район граничит с КНР. Районный центр г. Жаркент. В северной части района, вдоль предгорной наклонной равнины расположены населенные пункты села Коктал, УчАрал большой и малый Чеган, а также фермы крестьянских хозяйств. В центральной же части района встречаются лишь отдельные фермы отгонного животноводства [4].

Стратиграфия и литология. Восточная часть Илийской впадины почти повсеместно покрыта четвертичными образованиями. Древние осадочные породы выходят на дневную поверхность лишь в краевых участках бортов впадины. Горное обрамление представлено вулканогенно-осадочными и метаморфизованными образованиями палеозоя. В пределах впадины выделяются три структурных комплекса пород: докембрийско-нижнепалеозойские образования фундамента, среднепалеозойские отложения промежуточного этажа и осадочные отложения мезо-кайнозойского платформенного чехла $[1,2]$.

Палеозойская группа представлена кембрийской, ордовикской, каменноугольной и пермской системами.

Вулканогенно-метаморфические породы кембрия и ордовика слагают обособленные блоки в пределах горного обрамления (Улькен-Бугутты и Кетмень). 
Породы переходного средне-верхнепалеозойского комплекса представлены слабо дислоцированными толщами эффузивно-осадочных образований карбона и перми, залегающими с глубоким размывом на нижележащей толще.

Каменноугольная система представлена тремя отделами.

Нижний отдел сложен в низах базальтовыми, андезитовыми и даннитовыми порфиритами и их туфами темно-серого цвета, переходящими в эффузивы кислого состава (дацит-порфиры). Перекрываются эти образования массивными известняками.

Отложения среднего карбона представлены известняками и песчаниками и выявлены только в северо-восточной части впадины.

Верхнекаменноугольные отложения представлены эффузивами основного состава. Вскрыты они в скважине 4Т на Койбынской структуре.

Пермские породы установлены в разрезах глубоких скважин (3Г, 6Г, 7Г, 2Т, 4Г), в восточной, центральной и северной частях впадины [1].

Нижнепермские отложения подразделяются на две толщи. Нижняя эффузивная толща представлена лавами андезитовых и базальтовых порфиров. Эффузивно-осадочная толща, вскрытая скважинами повсеместно, представлена в низах разреза грубообломочными туфами, в средней части - переслаиванием эффузивов и туфов тонкой слоистости, и в верхней части - слоистыми туфопесчаниками.

Верхний отдел перми подразделяется на две толщи: нижнюю, представленную мелко галечными конгломератами и верхнюю хемогенно-терригенную, представленную не отсортированными песчаниками с прослоями алевролитов и пропластками известняка, ангидритов и гипсов.

Мезозойские отложения представлены угленосной толщей триас-юрского возраста и континентальной красноцветной полимиктовой толщей верхней юры - мела.

Триасовые отложения представлены переслаиванием в нижней части разреза крупнозернистых песчаников и разногалечных конгломератов, переходящих затем в голубовато-серые глины, аргиллиты и алевролиты с прослоями песчаников. Эти отложения вскрыты скважинами Усекской площади, а также на крайнем юго-востоке впадины.

Юрские отложения изучены по керну скважин Усекской площади, скважины 4т Кировской площади, а также глубоких скважин 3Г, 6Г, 7Г в левобережной части впадины.

Нижнеюрские отложения представлены грубозернистыми песчаниками, переходящими в алевролиты и аргиллиты. Встречаются маломощные пропластки бурых углей. В районе скважины Зг мощность отложений составила 308 м, западнее, в районе Усекской площади - 107-170 м и в пределах Приилийской площади юрские отложения выклиниваются.

Среднеюрские отложения представлены сменяющимися снизу-вверх песчаниками, алевролитами, углистыми аргиллитами и глинами с прослоями углей.

Верхнеюрские отложения слагают каолинизированные глины и алевролиты мощностью 20-35 м.

Отложения нижнего мела сложены в основном конгломератами и песчаниками с редкими прослоями глин и алевролитов. Конгломераты состоят из гальки и гравия эффузивных пород на глинисто-карбонатном цементе. Мощность отложений от 59 м на севере (скважина 4т) до 172 м в пределах Усекской площади, при средней мощности отложений 70-80 м [3].

Верхнемеловая светло-серая песчаная пачка распространена по всей впадине и вскрывается многими глубокими скважинами (3T, 1T, 2Т, 1ТП и др.). Толща сложена крупно-среднезернистыми песчаниками кварцевого состава, обычно 
слабосцементированными. В нижней части разреза кварц-полевошпатовые песчаники сменяются несколько более сцементированными слюдистыми песчаниками желтоватого цвета. В разрезе встречаются подчиненные прослои глин, аргиллитов и алевролитов. Общая мощность отложений до 130 м.

Отложения палеогена развиты в центральной и северо-западной частях впадины и выклиниваются в пределах южного и юго-западного бортов и представлены двумя свитами.

Отложения Кайчинской свиты несогласно залегают на меловых породах. Они характеризуются довольно однородным литологическим составом и представлены аргиллитоподобными глинами красного цвета с включениями гальки и маломощными прослоями плохо отсортированных песчаников, алевролитов и мергелей. Мощность отложений свиты составляет в среднем 90-120 м.

Отложения Джамбыл-Бастауской свиты развиты по северной половине впадины и представлены в нижней части разреза толщей разнозернистых песчаников и алевролитов, переходящих в глины и алевролиты с подчиненными прослоями песчаников. Средняя мощность свиты в центральной части впадины от 115 м (Усекская площадь) до 65 м (Приилийская площадь). В северном направлении мощность отложений свиты увеличивается до 288 м.

Неогеновые отложения распространены по всей площади впадины и вскрыты всеми поисковыми, а также многочисленными глубокими и гидрогеологическими скважинами. Они несогласно залегают на палеогеновых образованиях и представлены толщей континентальных моласс, разделяемой на три свиты.

Отложения Койбынской свиты представляют из себя в нижней части переслаивание кварцевых песчаников, крупногалечных конгломератов эффузивных пород на песчано-глинистом цементе. В средней части преобладают пески кварцевые, мелкозернистые и слабосцементированные песчаники на карбонатно-глинистом цементе. Верхняя часть разреза представлена песчанистыми глинами, алевролитами с тонкими прослоями песков, слабосцементированными песчаниками, гравелитами и мелкогалечными конгломератами. Мощность свиты возрастает с 400 м в восточной части впадины до 600 м в западной.

Четвертичная система представлена образованиями различного генезиса. Главным образом это валунно - и гравийногалечники, разнозернистые песчаники с прослоями глин. Мощность отложений, вскрытых большим количеством скважин достигает 330-400 м.

Тектоника. Жаркентская впадина представляет собой крупный межгорный прогиб, протягивающийся в субширотном направлении от Калкан-Богутинского перешейка на западе до реки Хоргос (государственная граница с КНР) на востоке на 140 км при ширине от 30 до 100 км.

На севере депрессия ограничивается антиклинорием Кату-Тау и Джунгарским Алатау, а на юге восточными отрогами Заилийского Алатау: антиклинорием Богуты, отрогами Кунгей Алатау и Кетменьским антиклинорием. Современный тектонический план депрессии окончательно оформился в альпийский геотектонический цикл, в плиоцен-четвертичное время. По характеру тектонического развития впадина делится на зону северного борта, центральную часть и зону южного борта.

Зона северного борта Джаркентской впадины с севера ограничена горными сооружениями Джунгарского Алатау и Пиджимским тектоническими нарушениями. В пределах этой зоны развиты адыроподобные антиклинальные складки. Разрывные нарушения хорошо выражены геологическими выходами более древних пород на дневную 
поверхность. В пределах зоны выделяется несколько линий складок разного размера, как правило, субширотно ориентированных.

Центральная часть впадины на севере ограничивается Актау-Хоргосским нарушением, на юге по линии Чунджа-Дубун - по серии протяженных, но мало амплитудных разломов субширотного простирания.

Здесь выделяются три структурно-тектонические зоны: Панфиловская (осевая), Пиджимско-Хоргосская (зона погребенных структур) и Борохудзирская (западная).

Осевая зона представляет собой крупный синклинальный прогиб с максимальными для всей депрессии глубинами погружения фундамента- до 5500 м.

На юге центральная часть прогиба плавно сочленяется с Предкетменьской моноклиналью южного борта, характеризующейся монотонным подъемом фундамента от 3800м до до выхода на поверхность в Кетменьском антиклинории. На востоке, западе и в южной прибортовой частях моноклиналь осложнена соответственно, Дубунским, ЧунджаДубунским, Чилико-Кеминским и другими более мелкими разломами.

Таким образом, из приведенных выше материалов видно, что фундамент Жаркентской впадины характеризуется блоковым строением. Широтные разломы, осложняющие северный и южный борта впадины имели определяющее значение при заложении впадины, и в мезозойское время контролировали общий процесс осадконакопления.

История геологического развития. В структурно-тектоническом плане район относится к южному крылу крупного Илийского синклинория, сформированного в среднем и верхнем палеозое.

Начиная с мезозоя, здесь отмечается новый этап геологического развития, характеризующийся формированием устойчивых областей поднятий и опусканий. Как и в верхнем палеозое, область максимального прогибания располагается в северной части описываемой площади, где с верхнего триаса формируется Илийская межгорная впадина. Область хр. Кетмень на данном этапе развития представляла собой приподнятую эродированную поверхность. В целом Жаркентская впадина ориентирована в юговосточном направлении. В сторону Кетменьского хребта наблюдается пологое возвышение южного борта впадины.

В результате проявления новокиммерийской фазы складчатости район испытывал общее поднятие и денудации, что подтверждается полным выпадением из мезозойских разрезов образований верхней юры и нижнего мела.

В верхнемеловую эпоху район Жаркентской депрессии испытывал кратковременное погружение. Породы верхнего мела залегают с размывом на отложениях верхнего триаса и средней юры, распространяясь в западном и восточном направлениях далеко за пределы описываемого района.

Начиная с олигоцена Жаркентская впадина вновь интенсивно прогибается. В конце плиоцена проявилась одна из фаз альпийского тектогенеза. В результате ее на месте хр. Кетмень формируется сводовое поднятие, осложненное разрывными нарушениями, которые разделили его на отдельные блоки, поднятые впоследствии на различные гипсометрические уровни. Наряду с поднятием горных сооружений происходили также интенсивные дифференциальные движения отдельных тектонических блоков палеозойского основания межгорной впадины. В описываемом районе к подобным структурам относится Дубунское поднятие, ядро которого сложено породами Илийской свиты. Северное крыло Дубунской структуры срезано сбросом широтного простирания. В четвертичный период продолжаются активные глыбовые перемещения, как горных сооружений, так и прилегающей впадины. 
Если на границе неогенового и четвертичного периодов альпийскими тектоническими движениями были заложены основные элементы современной горной области и межгорной впадины, то в начале среднечетвертичной эпохи происходит их окончательная дифференциация. На значительные (с амплитудой до 1000м) глыбовые перемещения этого времени указывают факты залегания нижнечетвертичных отложений на различных гипсометрических уровнях и их тектонические контакты по разломам с разновозрастными палеозойскими образованиями.

В средне - и верхнечетвертичную эпохи продолжается поднятие хребтов и прогибание межгорной впадины. С этим этапом развития связано образование современной гидрографической сети и формирование шлейфа конусов выноса. С началом среднечетвертичного времени связана новая активизация тектонической деятельности.

С началом позднечетвертичного периода связана новая активизация тектонических процессов. В Жунгарии развивается новое оледенение, заметно меньшее, чем среднечетвертичное. Подножие хр. Кетмень в это время испытывает слабое опускание. Здесь формировался мощный предгорный шлейф конусов выноса, ширина которого достигала 15-20км. К концу эпохи тектоническая активность района ослабевает.

Гидрогеологические условия. Согласно схеме гидрогеологического районирования Казахстана, разработанной академиком У. Ахмедсафиным (1964 и 1968гг.), Жаркентский артезианский бассейн является бассейном второго порядка по отношению к КопаИлийскому и расположен на его крайнем востоке [2].

Жаркентский артезианский бассейн является относительно крупным многоярусным бассейном, областями питания которого служит его горное обрамление с абсолютными отметками до 3500 м. Здесь выпадает значительное количество атмосферных осадков (до 500 мм в год), широко развиты ледники, что способствует образованию постоянного подземного стока во впадину, где формируются термальные воды с различными гидрохимическими и гидродинамическими параметрами.

По данным гидрогеологических исследований в разрезе Жаркентского артезианского бассейна выделяется семь водоносных комплексов: пермский, триасовый, юрский, меловой, палеогеновый, неогеновый и четвертичный. В составе первых четырех выделяются следующие термоводоносные горизонты: нижнепермский, верхнепермский, нижнетриасовый, нижнеюрский, среднеюрский, нижнемеловой и верхнемеловой.

Пермский термоводоносный комплекс вскрыт на крайнем юго-востоке бассейна скважинами Хоргосского профиля 3Т, 6Г и 7Г. Он приурочен к трещиноватым эффузивным образованиям перми, залегающих на глубинах от 1200 до 3000 м. Нижнепермский горизонт содержит хлоридно-натриевые воды с минерализацией 8.47 г/л. Воды напорные, самоизливающиеся, с дебитом порядка $30 \mathrm{~m}^{3} /$ сут и температурой на глубине $2992 \mathrm{M}-102^{0} \mathrm{C}$. В скв. 7Г при опробовании верхнепермского горизонта были получены воды того же состава, но с минерализацией 20.8 г/л. Температура воды на глубине 1231 м составила $56^{0} \mathrm{C}$.

Триасовый термоводоносный комплекс вскрыт скважинами Хоргосского профиля на глубинах от 1080 до 2280 м. Этот комплекс включает в себя два горизонта: нижне - и верхнетриасовый, разделенные глинистым водоупором среднетриасового возраста мощностью порядка 110 м.

Нижнетриасовый горизонт испытан в скв. 7Г, 3Г и 2Т на глубинах, соответственно $1132-1150,2215-2275$ и 2620-2830 м. Воды напорные, самоизливающиеся с избыточными давлениями от 1.5 до 31 атм. Дебиты скважин колеблются от 17.3 и 86 до 4700 м³/сут (скв. $3 Г$ ). Также существенно различается и минерализация вод. При этом, по мере погружения пород нижнего триаса минерализация вод резко возрастает с юга на север от 0.85 до 15.2 г/л. Состав вод различный, их пластовая температура колеблется от 38 до $81^{\circ} \mathrm{C}$. 
Верхнетриасовый горизонт содержит напорные воды (с избыточным давлением 18 атм), с дебитом $2500 \mathrm{~m}^{3} /$ сут (скв.7Г). Вода пресная, смешанного состава.

Юрский термоводоносный комплекс включает в себя два горизонта: нижнеюрский и среднеюрский, которые испытаны в скв. 7Г, 1Т и 3Т.

Нижнеюрский горизонт приурочен к пласту песчаников, залегающих в низах разреза, мощностью от 16 до 90 м. В скв. 1Т в интервале глубин 2612-2670 м получен приток воды с дебитом $240 \mathrm{~m}^{3} /$ сут и температурой $52^{0} \mathrm{C}$ на устье скважины. Вода сульфатно-натриевая с минерализацией 2,45 г/л.

Среднеюрский горизонт приурочен к пластам песчаников, залегающих в верхах разреза. В скв.7Г была получена хлоридно-кальциевая вода с минерализацией 0.99 г/л, дебитом $123 \mathrm{~m}^{3} /$ сут и температурой $22^{0} \mathrm{C}$. В пределах Усекской площади дебиты резко возрастаю от 1294 до $1723 \mathrm{~m}^{3} /$ сут и соответственно увеличивается температура воды, достигая $62-71^{0} \mathrm{C}$. Состав воды меняется на гидрокарбонатно-натриевый, и минерализация возрастает до 2.6 г/л.

Меловой термоводоносный комплекс включает в себя два горизонта: нижнемеловой и верхнемеловой, разделенных водоупором, который представлен пачкой глин, венчающих разрез нижнего мела. Мощность водоупора составляет от 10 до 25 м.

Нижнемеловой горизонт испытан в скв. 3Г, где был получен максимальный приток воды дебитом $5200 \mathrm{~m}^{3} /$ сут при избыточном давлении 26 атм. Воды сульфатногидрокарбонатно-натриевого состава с минерализацией от 0.8 до 2.3 г/л. Температура воды на устье скважин составила от 31 до $72^{\circ} \mathrm{C}$.

Верхнемеловой горизонт испытан в опорной скважине 1Г, а также в скв.3Т и 2Т Усекской площади. Дебиты составили порядка 4000-4310 м³/сут, воды ультрапресные, с минерализацией до 0.5г/л, по химическому составу гидрокарбонатные натриевые. Воды высоконапорные, с избыточными давлениями на устье скважин от 17 до 24 атм., температура воды изменяется от 67 до $96^{0} \mathrm{C}$ [5].

Таким образом Жаркентский артезианский бассейн характеризуется относительно простыми геолого-гидрогеологическими условиями. Термальные воды приурочены к меловым обводненным отложениям, при их спокойном залегании, не разбитом разрывными нарушениями. В связи с чем рассматриваемый участок (месторождение) относится к 1 группе месторождений термальных вод.

\section{Литературы}

1. Кан С.М., Муртазин Е.Ж., Вялов В.Д., Отчет о результатах разведочных гидрогеологических работ с подсчетом эксплуатационных запасов по скважине 3 Т по состоянию на 15.10.2016 г. -ТОО «ИГиГ имени У.М. Ахмедсафина», 2017 г., - 53 с.

2. Кан С.М., Муртазин Е.Ж., Вялов В.Д. Отчет о НИР «Оценка ресурсов, запасов и использование геотермальных, лечебных минеральных и промышленных вод Казахстана» ТОО «ИГиГ имени У.М. Ахмедсафина», 2013 г., - 120 с.

3. Месторождения подземных вод Казахстана. Справочник. Алма-Аты, 1999, Т3.

4. Муртазин Е.Ж., Байкадамова А.М., Кисмельева Б. Комплексное использование термальных вод скважины 3-Т Жаркентской впадины // Вестник КазНИТУ, выпуск №6, 2017, с. $37-45$

5. Baikadamova A. "Possibilities of using the Zharkent depression's thermal water"// Сборник международной научно-практической конференции «Современные проблемы гуманитарных и естественных наук», 2018 